\title{
PENGARUH PENAMBAHAN KULIT BUAH NAGA (Hylocereus polyrhizus) TERHADAP AKTIVITAS ANTIOKSIDAN, NILAI ORGANOLEPTIK DAN PROKSIMAT PADA KERUPUK IKAN TONGKOL (Euthynnus affinis)
}

Effect of Dragon Fruits Rind (Hylocereus polyrhizus) Additives on Antioxide Activity, Organoleptic Values, Proximate Analysis of Mackarel Tuna (Euthynnus affinis) Crackers

\author{
Ni Wayan Sugiantari1*, Kobajashi T. Isamu1, RH Fitri Faradilla2 \\ 1Jurusan Teknologi Hasil Perikanan, Fakultas Perikanan dan Ilmu Kelautan Universitas Halu Oleo, Kendari, \\ Sulawesi Tenggara, Indonesia \\ 2Jurusan IImu dan Teknologi Pangan, Fakultas Pertanian Universitas Halu Oleo, Kendari, Sulawesi Tenggara, \\ Indonesia \\ *Email korespondensi: niwayansugiantari18@gmail.com(Telp: +6282349413651) \\ Diterima: 10 Agustus Oktober/ Disetujui 25 September 2019
}

Cara sitasi: Sugiantari NW, Isamu KT, Faradilla RF. 2019. Pengaruh penambahan kulit buah naga (Hylocereus polyrhizus) terhadap aktivitas antioksidan, nilai organoleptik dan proksimat pada kerupuk ikan tongkol (Euthynnus affinis). Jurnal Fish Protech. 2(2):172-179.

\section{ABSTRACT}

The aim of this study was to determine the effect of adding dragon fruit skin (Hylocereus polyrhizus) on organoleptic characteristic, nutritional content, and antioxidan activity of tcobfish crackers (Euthynnus affinnis). This study used a Randomized Design) consisting of 3 treatments namely A (23\% tuna meat, 60\% tapioca flour and dragon fruit skin 17\%); treatment B (25\% tuna meat, $50 \%$ tapioca flour, dragon fruit skin $25 \%)$ and treatment $C$ (27\% tuna meat, $40 \%$ tapioca flour, dragon fruit skin 33\%). There were three replications each treatment, so that there were 9 experimental units. The results showed that the analysis of variance descriptive and hedonic tests. The highest value of appearance was treatment $C$ with descriptive and hedonic values respectively $(5,10$ and 3,14$)$. The highest values of aroma was treatment $A$ namely $(7,26)$. The highest value of taste was parameters $B(7.26)$, the highest value of textur was treatment $B(7.26)$ and the highest hedonic value of cripness was treatment $C$ (3.32). The addition of dragon fruit skin treatment did not significantly affect to organoleptic value of Cobfish crackers. The highest moisture content was treatment $B$ (1.94). The highest average value of ash was treatment $C$ (1.36). Treatment $C$ with the highest value (22.73). Protein treatment parameters $C$ with the highest value (26.14). The carbohydrate sample $A$ with the highest value. The results of the antioxidant activity test obtained the IC50 value of the US sample with a value (307.30), BS sample (277.00), CS sample $(278,57)$, $s$ ampel $A B$ (258, 86), BB samples (251.80) and CB samples (225.23).

Keywords: Crackers, dragon fruits rind, mackarel tuna, antioxidant activity

\section{ABSTRAK}

Tujuan penelitian ini adalah untuk mengetahui pengaruh penambahan kulit buah naga (Hylocereus polyrhizus) terhadap sipat organoleptik, kandungan gizi, dan aktivitas antioksidan kerupuk ikan tongkol (Euthynnus affinis). Penelitian ini menggunakan Rancangan Acak Lengkap (RAL) yang terdiri dari 3 perlakuan yaitu $\mathrm{A}$ (daging ikan tongkol $23 \%$, tepung tapioka $60 \%$, dan kulit buah naga $17 \%$ ), perlakuan B (daging ikan tongkol $25 \%$, tepung tapioka $50 \%$, kulit buah naga $25 \%$ ), dan perlakuan C (daging ikan tongkol 27\%, tepung tapioka $40 \%$, kulit buah naga $33 \%$ ). Masing-masing perlakuan dilakukan tiga kali ulangan, sehingga diperoleh jumlah satuan percobaan sebanyak 9 unit. Hasil penelitian menunjukkan bahwa analisis ragam uji deskriptif dan hedonik Nilai tertinggi untuk parameter penampakan adalah perlakuan $C$ dengan nilai deskriptif dan hedonik $(5,10$ dan 3,14. Nilai tertinggi untuk parameter aroma adalah perlakuan $A$ yaitu $(7,26)$. Parameter rasa tertinggi $B(7,26)$, tekstur tertinggi perlakuan $B(7,26)$ dan kerenyahan nilai hedonik tertinggi perlakuan $C$ $(3,32)$. Perlakuan penambahan secara statisitk tidak berpengaruh nyata terhadap nilai organoleptik kerupuk ikan tongkol. Pada uji kandungan gizi proksimat dengan nilai rata-rata parameter kadar air tertinggi pada perlakuan $B(1,94)$. Parameter abu dengan nilai rata-tertinggi pada perlakuan $C(1,36)$. Parameter lemak perlakuan $A$ perlakuan $C$ dengan nilai tertinggi (22,73). parameter protein perlakuan $C$ dengan nilai tertinggi $(26,14)$. Parameter karbohidrat sampel $A$ dengan nilai 
tertinggi. Hasil uji aktivitas antioksidan didapat nilai $I_{50}$ sampel AS dengan nilai $(307,30)$, sampel $B S(277,00)$, sampel CS $(278,57)$, sampel AB $(258,86)$, sampel BB $(251,80)$ dan sampel CB $(225,23)$.

Kata kunci: aktivitas antioksidan, Ikan tongkol, kerupuk, kulit buah naga

\section{PENDAHULUAN}

Indonesia merupakan negara kepulauan (archiplagic state) dengan 17.499 dan memiliki garis pantai sepanjang $104.000 \mathrm{~km} 2$ Kementrian Kelautan dan Perikanan, (2014). Indonesia memiliki sumberdaya ikan yang sangat besar diantaranya meliputi ikan tuna, cakalang, tongkol, tenggiri, kakap, cumi-cumi, ikan karang, ikan hias, kerang dan rumput laut, tetapi belum termanpaatkan secara maksimal Adisanjaya, (2010).

Ikan tongkol termasuk pamilia scorombidae yang merupakan salahsatu jenis ikan konsumsi. (oktaviani, 2008). Nilai produksi tangkapan ikan tongkol tahun- ketahun semakin meningkat hal ini dapat dilihat pada data statistik dari kementrian kelautan dan perikanan yang menyebutkan bahwa hasil tangkapan ikan tongkol pada tahun 2009 1.420.039.707 ekor dan meningkat pada tahun 2010 yaitu 1.454.305.423 ekor. Sehingga hal ini yang menyebabkan peningkatan produksi penangkapan yang tinggi daya simpan ikan tongkol yang cepat mengalami kemuduran mutu dan mudah rusak disebabkan kadar air yang tinggi (Kementrian Kelautan dan Perikanan, 2010).

Salah satu cara pengolahan ikan untuk meningkatkan nilai tambah dan umur simpan adalah dengan mengolah menjadi kerupuk ikan yang dimana kerupuk ikan merupakan salah satu olahan produk tradisional yang digemari oleh masyarakat Indonesia. Makanan tersebut dikenal disegala usia maupun tingkat sosial masyarakat. Mudah diperoleh dan dijual dengan harga murah baik dalam kemasan yang sudah digoreng maupun dalam kemasan yang masih mentah (Koswara, 2009).

Kandungan ikan tongkol mempunyai nutrisi yang tinggi terutama protein yaitu antara 22,6-26,2 $\mathrm{g} / 100 \mathrm{~g}$ daging, lemak antara 0,2-2,7 g/100 g daging, dan beberapa mineral (kalsium, fosfor, besi, sodium), vitamin $A$ (retinol), dan vitamin $B$ (thiamin, riboflavin dan niasin) (Departemen of Health Education and Walfare 1972 dalam Maghfiroh, 2000). Protein dan lemak pada ikan tongkol yang sangat tinggi menyebabkan produk bila disimpan lama, mengalami oksidasi atau bau tengik dari produk. Untuk mengatasi hal ini diperlukan bahan tambahan seperti antioksidan yang dapat menghambat proses oksidasi dan menghambat terjadinya pembusukan oleh bakteri patogen dalam produk (Soedibyo, 1999).

Sumber antioksidan terdapat dalam kulit dan daging buah naga. Manfaat yang ditemukan pada daging buahnya, kulit buah naga juga mengandung zat-zat yang dapat memberikan manfaat. Seringkali orang beranggapan bahwa kulit buahnya tidak dapat dimanfaatkan dan akhirnya dibuang. Padahal banyak sekali manfaat yang bisa diambil dari kulit buah naga. kulit buah naga merah ditemukan positif mengandung senyawa alkaloid, steroid, saponin, dan tanin serta vitamin C. Alkaloid adalah senyawa basa bernitrogen yang dihasilkan tumbuhan atau bahan tumbuhan yang mengandung nitrogen dan larut dalam air.

Kandungan dalam kulit buah naga yang dapat dimanfaatkan sebagai sumber antioksidan yang tinggi. Antioksidan adalah salah satu kelas dari senyawa flavonoid secara luas terbagi dalam polifenol tumbuhan yang larut dalam air serta tersebar luas dalam bunga, kulit, daun menghasilkan warna dari merah sampai biru (Winarno, 1997).

Selama ini penambahan bahan tambahan yang digunakan dalam pembuatan kerupuk berasal dari jenis ikan tenggiri, ikan sapu-sapu dan udang oleh karena itu, diperlukan alternatif bahan tambahan lain untuk membuat kerupuk, salah satu bahan tambahan yang digunakan adalah daging ikan tongkol dan kulit buah naga. Salah satu upaya untuk meningkatkan kandungan gizi pada kerupuk serta meningkatkan nilai tambah pada produk kerupuk. 


\section{METODE PENELITIAN}

\section{Alat dan Bahan}

Bahan yang digunakan dalam penelitian ini adalah: ikan tongkol yang di beli di TPI (Tempat Pelelangan Ikan) Sodohoa Kendari dengan kenampakan masih terlihat segar tanpa bau amis dan mata ikan masih berwarna bening, kulit buah naga, tepung tapioka, dan minyak goreng. Bahan lain yang digunakan adalah bawang putih, ketumbar, merica, soda kue, aquades, larutan DPPH $4 \mathrm{mg}$ di gunakan untuk uji antioksidan, methanol p.a, aluminium foil, dan air.

Alat yang digunakan dalam penelitian ini antaralain: pisau, tampah, blender, kertas label, kompor gas, wajan, spatula, timbangan digital, sendok, garpu, saringan, plastik, panci kukus, baskom, centong, talenan, nampan, timbangan analitik, gelas ukur, pipet ukur, tabung reaksi, beaker glass, rak tabung reaksi, Erlenmeyer, labu takar $100 \mathrm{ml}$, labu takar $5 \mathrm{ml}$, kertas saring, kertas label, vortex, spektrofotometer uv-vis dan blue tip $1 \mathrm{ml}$, kuvet, lumpang dan alu.

\section{Prosedur Penelitian}

Adapun Prosedur penelitian ini dilakukan dengan langkah-langkah sebagai berikut

\section{Penyiapan Bahan Baku}

Ikan tongkol segar yang diperoleh dari TPI (Tempat Pendaratan Ikan) bertempat di kecamatan Sodohoa Kendari Barat, ikan dikemas menggunakan boks yang berisikan es langsung dibawa untuk dibersihkan dengan memisahkan kepala, insang, tulang serta kulit ikan tongkol dan dicuci hingga bersih menggunakan air es. Setelah daging ikan sudah bersih, daging ikan dilumatkan (dihaluskan) menggunakan meat grinder dan ditimbang sesuai dengan kebutuhan yaitu sebanyak $23 \%, 25 \%$, dan $27 \%$. Setelah itu kulit buah naga juga dibersihkan dipotong kecil-kecil dihaluskan menggunkan blender ditimbang sesuai dengan kebutuhan sebanyak, $17 \%$, $25 \%$, dan $33 \%$.

\section{Pembuatan Adonan}

Pembuatan adonan adalah pencampuran semua bahan hingga homogen. Tepung tapioka, daging ikan tongkol, dan air, kulit buah naga yang sudah di blender dengan bumbu-bumbu yang sudah dihaluskan dicampur dan diuli menggunakan tangan, pencampusran ini dilakukan selama 15 menit hingga terbentuk adonan yang homogen. Adonan tersebut apabila dipegang dengan tangan tidak lengket, menunjukkan pengadonan telah cukup.

\section{Pengukusan}

Adonan yang telah berbentuk lontongan kemudian dimasukan kedalam pencetakan kerupuk yang telah dilapisi daun pisang dengan menggunakan pencetak kerupuk (selongsong stainless steel) kemudian dikukus hingga matang selama 2 jam pada suhu 100 oC. Cara untuk mengetahui adonan yang dikukus telah matang yaitu ditusuk dengan menggunakan lidi ke dalam adonan dan tarik, apabila adonan masih menempel pada lidi menandakan adonan belum matang dan sebaliknya jika tidak ada adonan yang menempel pada lidi menandakan adonan sudah matang.

\section{Pengirisan}

Adonan yang telah matang, kemudian diangkat dari penangas kemudian disimpan dalam suhu ruang 27-31 oC selama 24 jam sampai dingin dan mengeras, setelah dingin diris dengan ketebalan $3 \mathrm{~mm}$ dengan menggunakan pisau.

\section{Pengeringan (Penjemuran)}

Pengeringan atau penjemuran yang dilakukan dalam penelitian ini adalah dengan menggunakan pengeringan alami. Pengeringan alami yaitu pengeringan dengan menggunakan sinar matahari, dimana adonan matang yang telah diris diatur di atas para-para atau alas bersih kemudian dijemur di bawah sinar matahari. Pengeringan atau penjemuran dilakukan selama 1-3 hari, kerupuk mudah dipatahkan menandakan kerupuk telah kering. Tujuan pengeringan adalah untuk mengurangi kadar air bahan sampai batas dimana perkembangan 
mikroorganisme yang dapat menyebabkan pembusukan terhambat, demikian juga perubahanperubahan akibat aktivitas enzim. Keuntungan dari pengeringan antara lain bahan menjadi awet, dengan volume bahan yang lebih kecil sehingga memudahkan dan menghemat ruang pengepakan dan pengangkutan dengan demikian diharapkan biaya produksi menjadi lebih murah (Winarno dan Fardiaz, 1980).

\section{Penggorengan}

Penggorengan kerupuk dilakukan untuk mendapatkan kerupuk matang. Menurut Siswantoro (2008), ditinjau dari segi waktu proses pemasakan, penggorengan adalah salah satu cara pemasakan produk pangan yang dilakukan secara cepat, dan cara ini dianggap paling efisien proses transfer panasnya ke produk pangan yang dimasak. Tahap penggorengan ini adalah melakukan penggorengan dengan cara deef fat frying. Kerupuk yang sudah kering digoreng dengan menggunakan minyak goreng. Suhu yang digunakan dalam penggorengan yaitu 120 oC selama 15-20 detik diukur menggunakan termometer suhu minyak goreng (Alfisyahrica, 2015).

\section{Rancangan penelitian}

Penelitian ini menggunakan metode eksperimen dengan menggunakan rancangan acak lengkap (RAL) yang terdiri dari tiga perlakuan dimana perlakuan $A$ (daging ikan tongkol $23 \%$, tepung tapioka $60 \%$, dan kulit buah naga 17\%), perlakuan B (daging ikan tongkol $25 \%$, tepung tapioka $50 \%$, kulit buah naga $25 \%$ ), dan perlakuan C (daging ikan tongkol $27 \%$, tepung tapioka $40 \%$, kulit buah naga $33 \%$ ). Masingmasing perlakuan dilakukan tiga kali ulangan, sehingga diperoleh jumlah satuan percobaan sebanyak 9 unit.

\section{Parameter uji}

Uji sensori (Soekarto, 1985) analisis uji kimia berupa kadar air, kadar abu, kadar protein , kadar lemak,dan karbohidrat dilakukan melalui analisis proksimat. Analisis proksimat merupakan pengujian kimia untuk mengetahui kandungan zat gizi suatu bahan pangan atau pakan. Analisis proksimat dilakukan meliputi kadar air (AOAC 1995) kadar abu (AOAC 1995) Kadar protein metode spektrofotometer (AOAC 2005) kadar lemak metode soxhlet (AOAC 2005) kadar karbohidrat by difference (Winarno, 2008) analisis uji antioksidan menggunakan DPPH (Fitrianingsih, 2014).

\section{HASIL DAN PEMBAHASAN}

\section{Hasil}

\section{Hasil uji sensori kerupuk ikan tongkol secara deskriptif}

Nilai rata-rata produk kerupuk ikan tongkol terhadap penilaian uji deskriptif disajikan pada Tabel 1.

Tabel 1. Nilai rata-rata sensori uji deskriptif

\begin{tabular}{lccc}
\hline \multicolumn{1}{c}{ Parameter } & A & B & C \\
\hline Kenampakan $\pm S D$ & $6,40 \pm 0,30$ & $6,13 \pm 0,61$ & $5,10 \pm 0,75$ \\
Aroma $\pm S D$ & $7,26 \pm 0,40$ & $7,24 \pm 0,30$ & $7,16 \pm 0,28$ \\
Rasa $\pm S D$ & $7,16 \pm 0,28$ & $7,26 \pm 0,11$ & $7,20 \pm 0,15$ \\
Tekstur \pm SD & $7,16 \pm 0,28$ & $7,26 \pm 0,11$ & $7,20 \pm 0,15$ \\
\hline
\end{tabular}

Keterangan:

SD; Standar Deviasi

A: Penambahan daging ikan tongkol 23\% dan kulit buah naga $17 \%$

B: Penambahan daging ikan tongkol 25\% kulit buah naga $25 \%$

C: Penambahan daging ikan tongkol $27 \%$ kulit buah naga $33 \%$

Hasil uji sensori kerupuk ikan tongkol secara hedonik.

Nilai rata-rata produk kerupuk ikan tongkol terhadap penilaian uji hedonik disajikan pada Tabel 2.

Tabel.2 nilai rata-rata sensori uji hedonik

\begin{tabular}{llll}
\hline Parameter & $\mathrm{A}$ & $\mathrm{B}$ & $\mathrm{C}$ \\
\hline Kenampakan $\pm S D$ & $3,11 \pm 1,21$ & $3,11 \pm 1,21$ & $3,14 \pm 1,20$ \\
Aroma \pm SD & $3,08 \pm 1,10$ & $3,13 \pm 1,15$ & $3,37 \pm 1,14$ \\
Rasa \pm SD & $3,09 \pm 1,07$ & $3,11 \pm 1,10$ & $3,35 \pm 1,02$ \\
Kerenyahan \pm SD & $3,01 \pm 1,10$ & $3,05 \pm 1,14$ & $3,32 \pm 1,02$ \\
Tekstur $\pm S D$ & $2,92 \pm 0,91$ & $2,95 \pm 0,94$ & $3,13 \pm 0,81$ \\
\hline
\end{tabular}

Keterangan: 


\section{SD; Standar Deviasi}

A: Penambahan daging ikan tongkol $23 \%$ dan kulit buah naga $17 \%$

B: Penambahan daging ikan tongkol $25 \%$ kulit buah naga $25 \%$

C: Penambahan daging ikan tongkol $27 \%$ kulit buah naga $33 \%$

\section{Hasil Analisis Proksimat Kerupuk Ikan Tongkol yang Setelah Digoreng}

Hasil analisis proksimat kerupuk ikan tongkol meliputi kadar air, kadar abu,kadar lemak, protein dan karbohidrat disajikan pada Tabel 3.

Tabel 3. Hasil analisis kandungan proksimat kerupuk ikan tongkol

\begin{tabular}{llllc}
\hline Parameter & A & B & C & SNI \\
\hline Air (\%) & 1,79 & 1,94 & 2,41 & Maks 12 \\
Abu(\%) & 1,31 & 1,34 & 1,36 & Maks 1 \\
Lemak(\%) & 15,54 & 19,75 & 22,73 & - \\
Protein (\%) & 19,76 & 21,04 & 26,14 & Min 5 \\
karbohidrat (\%) 61,6 & 55,93 & 47,36 & - \\
\hline
\end{tabular}

Keterangan:

A: Penambahan daging ikan tongkol $23 \%$ dan kulit buah naga $17 \%$

B: Penambahan daging ikan tongkol $25 \%$ kulit buah naga $25 \%$

C: Penambahan daging ikan tongkol $27 \%$ kulit buah naga $33 \%$

\section{Analisis aktivitas antioksidan}

Hasil analisis kandungan antioksidan kerupuk ikan tongkol dapat dilihat pada Tabel.4

Tabel 4. Hasil analisis kandungan antioksidan kerupuk

\begin{tabular}{lll}
\multicolumn{2}{c}{ ikan tongkol } \\
\hline Sampel & Persamaan linear & IC $50(\mathrm{ppm})$ \\
\hline AS & $\mathrm{y}=0,121 \mathrm{x}+12,187$ & 307,30 \\
BS & $\mathrm{y}=0,104 \mathrm{x}+21,192$ & 277,00 \\
CS & $\mathrm{y}=0,097 x+22,979$ & 278,57 \\
AB & $y=0,098 x+24,632$ & 258,86 \\
BB & $y=0.107 x+23,057$ & 251,80 \\
CB & $y=0,126 x+21,621$ & 225,23 \\
\hline
\end{tabular}

Keterangan:
A : Penambahan daging ikan $23 \%$, kulit buah naga $17 \%$

B : Penambahan daging ikan tongkol 25\%, kulit buah naga $25 \%$

C : Penambahan daging ikan tongkol $27 \%$, kulit buah naga $33 \%$

B : Belum digoreng

$S$ : Sudah digoreng

\section{Pembahasan}

\section{Kenampakan}

Berdasarkan pengujian sensori deskriptif dan hedonik kenampakan produk olahan kerupuk ikan tongkol memperlihatkan nilai rata-rata berpengaruh tidak nyata pada setiap perlakuan, perlakuan A uji deskriptif dengan nilai rata-rata 6,4 dengan kriteria kenampakan utuh, rapi, bersih, kurang homogen, ketebalan kurang rata, warna cream keputihan,sedangkan uji hedonik perlakuan $\mathrm{C}$ dengan nilai rata-rata 3,41 dengan kriteria agak suka berbeda tidak nyata $(P \leq 0,05)$ pada kenampakan kerupuk ikan tongkol. Hal ini dikarenakan penambahan konsentrasi daging ikan dan kulit buah naga terlalu sedikit. Hasil ini sesuai dengan penelitian Firliyanti, (2009) tentang pemanfaatan limbah udang sebagai alternatif bahan pengolahan kerupuk, dalam penelitian tersebut dinyatakan bahwa perbedaan penambahan limbah udang dalam pembuatan kerupuk ikan tidak mempengaruhi nilai organoleptik kenampakan.

\section{Aroma}

Hasil dari uji sensori uji deskriptif dan hedonik aroma dari produk olahan kerupuk ikan tongkol dihasilkan nilai rata-rata tidak berpengaruhnyata dari setiap sampel produk perlakuan A dengan nilai ratarata 7,26 dengan kriteria aroma ikan sedikit, sedangkan uji hedonik perlakuan $C$ dengan nilai ratarata 3,37 agak suka berbeda tidak nyata $(P \leq 0,05)$, pada aroma kerupuk ikan tongkol. Hal ini dikarenakan penambahan konsentrasi daging ikan tongkol yang sedikit dan segar yang memiliki aroma yang khas yang tidak mempengaruhi secara signipikan produk kerupuk ikan tongkol yang dibuat. Menurut Veni, 
(2014) yang menyatakan bahwa panelis beranggapan bahwa tepung terigu dan daging siput sawah pada kerupuk tetap memberikan aroma dari siput namun belum mempengaruhi aroma terhadap hasil akhir kerupuk.

\section{Rasa}

Berdasarkan penelitian hasil dari uji sensori deskriptif dan hedonik rasa dari produk olahan kerupuk ikan tongkol dihasilkan nilai rata-rata tidak berpengaruhnyata dari sampel produk perlakuan $B$ dengan nilai rata-rata 7,26 dengan kriteria ikan sedikit, sedangkan pada uji hedonik perlakuan $C$ dengan nilai rata-rata 3,35 dengan kriteria agak suka. berbeda tidak nyata $(P \leq 0,05)$, pada rasa kerupuk ikan tongkol. Hal ini disebabkan konsetrasi penambahan daging ikan yang terlalu sedikit dapat mempengaruhi nilai rasa yang kurang ggurih. Menurut penelitian Tambrin et al. ( 2018) menyatakan bahwa penurunan nilai rasa kerupuk kalandue disebabkan oleh penambahan tepung tapioka yang lebih banyak dibanding daging kerang kalandue, sehingga rasa daging kalandue yang terdapat dalam kerupuk lebih sedikit. Penambahan daging kalandue yang berbeda dalam pembuatan kerupuk tidak memberikan perbedaan yang signipikan terhadap nilai rasa kerupuk kalandue.

\section{Tekstur}

Berdasarkan hasil dari uji organoleptik deskriptif dan hedonik tekstur dari produk olahan kerupuk ikan tongkol didapat nilai rata-rata tidak berpengaruh nyata dari sampel produk kodesampel $B$ dengan nilai ratarata 7,26 dengan kriteria kering getas, sedangkan pada uji hedonik kodesampel $C$ dengan nilai rata-rata 3,13 dengan kriteria agak suka. Berbeda tidak nyata $(P \leq 0,05)$, pada kerupuk ikan tongkol. Hal ini disebabkan karena semakin sedikit penambahan daging ikan maka semakin getas kerupuk yang dihasilkan. Menurut pendapat (Ratnawati 2013) komposit tepung tapioka yang lebih banyak akan menghasilkan kerupuk ikan tekstur sangat ideal.

\section{Kerenyahan}

Hasil dari uji sensori hedonik kerenyahan dari produk olahan kerupuk ikan tongkol dihasilkan nilai rata-rata tidak berpengaruh nyata dari setiap sampel produk perlakuan $\mathrm{C}$ dengan nilai rata-rata 3,32 agak suka. Berbeda tidak nyata $(P \leq 0,05)$, pada kerenyahan kerupuk ikan tongkol. Hal ini dikarenakan penambahan konsentrasi daging ikan tongkol yang sedikit yang menyebabkan daya renyah pada produk menjadi garing dan krenyes yang tidak mempengaruhi secara signipikan produk kerupuk ikan tongkol yang dibuat. Menurut Veni (2014) yang menyatakan bahwa panelis beranggapan bahwa tepung terigu dan daging siput sawah pada kerupuk tetap memberikan daya renyah dari siput namun belum mempengaruhi daya renyah terhadap hasil akhir kerupuk.

\section{Kandungan Proksimat}

Kandungan proksimat pada krupuk ikan tongkol parameter yang diuji yaitu kadar air, abu, protein, lemak dan karbohidrat yang dimana kadar air yang di dapat semakin tinggi penambahan kulit buah naga semakin meningkat kadar air yang diperoleh diduga kulit buah naga mengandung kadar air yang tinggi, sedangkan untuk kadar abu, protein dan lemak dipengaruhi oleh penambahan daging ikan semakin tinggi konsentrasi daging ikan yang ditambahkan maka semakin meningkat kadar abu protein dan lemak yang di dapatkan diduga ikan banyak mengandung lemak, protein, dan mineral. Untuk kadar karbohidrat disebabkan oleh penambahan konsentrasi tepung yang semakin meningkat maka kadar karbohidrat yang diperolehpun semakin tinggi, diduga tepung tapioka memiliki kadar karbohidra yang tinggi.

\section{Kandungan Antioksidan}

Antioksidan merupakan senyawa yang mampu memperlambat laju oksidasi. Pemberian kulit buah naga sangat berpengaruh terhadap aktifitas antioksidan . kulit buah naga merupakan limbah hasil pertanian yang mengandung antosianin yang cukup tinggi (Handayani, 2012 ) menyatakan bahwa kulit buah naga mengandung antosiani lebih tinggi daripada daging buah naga yaitu sebesar 22,59335 
ppm. Pada penelitian ini, pengujian aktivitas antioksidan dilakukan dengan menggunakan metode DPPH pada panjang gelombang $516 \mathrm{~nm}$. Berdasarkan nilai persentase penghambatan dari ekstrak $C$. racemosa yang diperole, terlihat grafik yang semakin meningkat seiring dengan meningkatnya konsentrasi yang digunakan. Artinya, semakin tinggi konsentrasi, semakin besar pula daya hambat ekstrak terhadap radikal bebas (DPPH).

Berdasarkan hasil pada uji aktivitas antioksidan menggunakan metode DPPH terhadap kerupuk ikan tongkol diperoleh nilai dari kode sampel AS sebesar 307,30 ppm BS sebesar 277,000 ppm CS sebesar 278,57 ppm sedangkan kode sampel kerupuk sebelum digoreng $A B$ sebesar 258,86 ppm BB sebesar 251,80 ppm CB sebesar 225,23 ppm yang diperoleh memperlihatkan bahwa penambahan bubur kulit buah naga tergolong lemah hal ini dikarenakan adanya pemanasan tinggi pada waktu proses pemasakan berlangsung pada pembuatan kerupuk ikan tongkol hasil ini berbanding berbalik dari penelitian Rahmawati, (2012) konsentrasi antioksidan yang tinggi.

\section{KESIMPULAN}

Berdasarkan hasil penelitian dan pembahasan, maka dapat disimpulkan sebagai berikut :

1. Pengaruh penambahan kulit buah naga berbeda tidak nyata pada sifat organoleptik kerupuk ikan tongkol

2. Pengaruh kandungan gizi kerupuk ikan tongkol didapat hasil bahwa kadar air produk meningkat seiring meningkatnya penambahan bahan kulit buah naga, kandungan ikan tongkol dalam kerupuk dapat mempengaruhi kadar protein semakin tinggi penambahan daging ikan maka semakin meningkat kandungan protein, lemak dan abu dalam kerupuk.

3. Terdapat pengaruh penambahan kulit buah naga terhadap kandungan antioksidan semakintinggi detet konsentrasi semakin lemah IC 50 meskipun secara keseluruhan aktivitas antioksidan tergolong lemah.
DAFTAR PUSTAKA

AOAC.1995. Official Methods of Analysis of The Association of Analytical Chemist. Washington D.C. .2005. . Official Methods of Analysis of The Association of Analytical Chemist. Washington D.C.

Adisanjaya. 2010. Potensi Sumber Daya Ikan Diperairan Laut Indonesia dan Permasalahannya. EAPM

Alfisyarica. 2015. Variasi Bagian Telur Dan Presentase Dengan Daging Ikan Pada Proses Pengolahan Amplang Ikan Lele (Clarias gariepinus). [Skripsi] Jurusan Teknologi Hasil Pertanian. Fakultas Teknologi Pertanian. Universitas Jember.

Depertement Of Healt Education and Walfare. 2000. Kandungan Ikan Tongkol Mmpunyai Nutrisi Protein, Lemak Kalsium dan Mineral dalam 100 gram Daging.

Dwihandita, N. 2009. Perubahan Kandungan Antioksidan Anggur Laut (Caulerpa racemosa) Akibat Pengolahan [Skripsi]. Program Studi Teknologi Hasil Perikanan.

Firliyanti. 2009. Pemanfaatan Limbah Udang Sebagai Pembuatan Kerupuk. Semarang. PT.Gramedia.

Huda. 2010. Chimecal Composition Colour and Linear Expasion Proporties of

Handayani. 2012.Kulit Buah Naga Mengandung Antioksidan Lebih tInggi Dibanding Daging Buahnya. Jurnal Gizi dan Pangan. No 5. Vol. 4.

Malaysian Comersial Fish Chracker (keropok). Asian Jurnal of Fooda and Agro-Industri.Vol. 3 No. 437.

2009. The Effect of Different Ratias of Dary Fish on Tapioca Flour on The Linear Expasion. Internasional Food Research Journal. Vol. 16 No 159.

Jaafar, Ali, R. 2009. Prokximate Analisis Of Dragon Fruit (Hylecereus Polyhuzus). American Journal Of Aflied Scienes. Vol. 6. No. 13411346

Koswara. 2009. Teknologi Pengolahan (Teori dan Praktek). eBook Pangan. Com.diakses pada tanggal 21 November 2018.

Kementrian Kelautan dan Perikanan. 2014. Data Wilayah Indonesia Keputusan Mentri 
Kelautan Perikanan Indonesia. Nomor. 107/KEPMEN -KP.

Kementerian Kelautan dan Perikanan. 2010. Rencana Pengolahan Perikanan Tuna Cakalang dan Tongkol. Nomor 107/KEPMEN-KP/2015

Nurfadillah. 2016. Analisis Antioksidan Ekstrak Etil Asetat dari Kulit Buah Rambutan dengan Menggunakan Metode DPPH. Jurnal AlKimia. Nomor.1. Volume.4.

Rekna Wahyuni, 2011. Pemanaatan Kulit Buah Naga Super Merah sebagai Sumber Antioksidan dan Pewarna Alami pada

Ratnawati. 2013. Komposit Tepung Tapioka yang Banyak Menghasilkan Kerupuk Ikan yang Ideal. Teknologi Pangan.

Pembuatan Jeli. Jurnal Gizi dan Pangan. No. 2. Vol. 1.

Soekarto 1985. Penelitian Organoleptik untuk Industri Pangan dan Hasil Pertanian. Jakarta. Barata Karya Aksara.

Soedibyo. 1999. Protein dan Lemak dalam Ikan Tongkol dapat Menyebabkan Oksidasi yang Sangat Cepat. Jakarta. Suadaya.

Saanin. 1968. Taksonomi 2 Kunci Identipikasi Ikan 1. Jakarta. Binacipta.

Sudarmaji. 1997. Prosedur Analisis Bahan Makanan dan Pertanian. Liberty. Yogyakarta.

Sudarmadji, S.B. Haryono, Suhardi. 2007. Analisa Bahan Makanan dan Pertanian. Penerbit Liberty. Yogyakarta.

Suprapti. 2005. Tepung Tapioka. Yogyakarta. Kanisius

Standar Nasional Indonesia. 1997. SNI 01-2713-1997 Syarat Mutu Kerupuk Ikan. Badan Standar Nasional Indonesia. Jakarta.

Susanti. 2007. Difertifkasi Produk dengan Penambahan Daging Ikan Layur. Sekripsi Program Studi Hasil Perikanan. Fakultas Teknologi Industri. Institut Sain dan Teknologi. AKPRIND. Yogyakarta

Tarwotjo, 1998. Komposisi Kimia Ikan Tongkol. Jakarta: Grasindo

Tambrin et al. 2018.Kajian Kualitas Sensori dan Proksimat Kerupuk dengan Proposi Daging Kalandue dan Tepung Tapioka.

Veni. 2014. Uji Sensori Kerupuk Siput. Semarang. Grasindo.

Wagiyono. 2003. Menguji kesukaan secara organoleptik, bagian proyek pengembangan Kurikulum. Direktorat Jenderal Pendidikan

\author{
Dasar dan Menengah.Departemen \\ Pendidikan Nasional.
}

Wu, Li-chen, Hsu, Hsiu-Wen, Chen, Yun-Chen, Chiu, Chih-Chung, Lin, Yu-In and Annie Ho. Ja-an. 2006. Antioksidan and Antiprolifarative Of Red. Pitaya Food Chemistry. Vol. 95. No. 319-327

Winarno. 1980. Pengantar Teknologi Pangan. Jakarta. PT. Gramedia . 1997. Kandungan Kulit Buah Naga yang dapat Dimanfaatkan Sebagai Sumber Antioksidan. Jakarta. PT. Gramedia 